\title{
Legal Education at the University of Córdoba (1767-1821): From the Colony to the Homeland
}

\author{
A Reinterpretation of the Salamanca Tradition from a New Context
}

\author{
Esteban Llamosas
}

Introduction. University, Theology, and Law: A Reinterpretation of the Salmantine Legal Tradition

The Collegium Maximum of the Society of Jesus, which later became the University of Córdoba del Tucumán, was founded at the beginning of the 17th century during the heyday of the School of Salamanca. In that period, the city of Córdoba was part of the governorate (gobernación) of Tucumán in the Viceroyalty of Peru - and it later became part of the new Viceroyalty of Río de la Plata in 1776. The Collegium Maximum began to offer lectures in arts and theology in 1613, following some problems with income, and in 1621, a papal brief issued by Gregory XV granted it permission to award degrees. Regulated by the ordinances of Father Oñate, its early activities developed along the lines of the Salamancan model. ${ }^{1}$

Although there were already a few books for the instruction of the novices, the university began to build up a library shortly after its foundation, which soon became the most important library in Tucumán and the Río de la Plata area as it grew, thanks to the acquisitions made by procurators in Europe, donations, and bequests. By the mid-18th century, the library had more than 10,000 volumes. ${ }^{2}$ Catalogued meticulously in 1757 , it is worth noting - for our purposes - that the preponderant holdings were in the fields of Second Scholasticism and legal genres of the later ius commune. ${ }^{3}$

Although the university was not legally constituted until its official establishment in the late 18 th century, legal matters were already being debated

1 Rodríguez Cruz, Salmantica docet: la proyección de la Universidad de Salamanca en Hispanoamérica. However, as stated in chapter two of this volume, it is necessary to avoid taking the "paternalistic approaches" of Salamanca and the Spanish-American universities and the idea that the affinity of the statutes and constitutions necessarily means a high degree of similarity between universities.

2 Fraschini, Index Librorum Bibliothecae Collegii Maximi.

3 Llamosas, La literatura jurídica de Córdoba del Tucumán en el siglo XVIII, 206-214. 
in the faculty of theology through discussions about moral systems and the source of political authority, and the teaching of the canons. In a social order governed more by religion than by law, this link between the disciplines is not surprising. ${ }^{4}$ Therefore, legal-moral literature is an excellent key to unlock that order, which is not necessarily unfathomable by other means. Moral treatises, summaries, and cases of conscience, instructions for penitents, manuals for confessors, and sermons were all closely related to procedural practices, advisory documents for magistrates, and judicial-style manuals.

One of the most visible points of contact between law and moral theology in the ancien régime is casuistry, which abounded in the literary genres of both disciplines. The long legal tradition of the topic, the attention to individual cases along with their circumstances, the preference for particular (sometimes contradictory) resolutions, and the value placed on the opinion of doctors and fairness over and above general and abstract rules were given corresponding expression in the moral treatises where the doubtful cases of conscience were debated. Since the Middle Ages, the jurists' way of reasoning - especially that of a long-lived mos italicus that was rooted in Spanish-America - was identical to that of the moralists who presented concrete cases in their works, explained the various, opposing reasons supported by their respective authorities, and concluded with an individual resolution, also supported by doctors, which was consistent with the school of thought to which they subscribed. ${ }^{5}$ The characteristic features of ancien régime justice and judiciary, typical of a clearly jurisdictional culture which accepted that magistrates must preserve and guarantee established balances and roles, cannot be understood in isolation from religious discourse and that of its mediators, the theologians. ${ }^{6}$

After the expulsion of the Jesuits, the Franciscans were entrusted with running the University of Córdoba del Tucumán until the beginning of the 19th century when it came under the control of the city's secular clergy. With regard to the late colonial period, by studying the schools of moral thought which were spread by teachers between the second half of the 18th century and the early decades of the 19th century, we will gain a better understanding of the legal features of Cordovan society, including the forensic practice of its courts. There was a theological sector which interpreted and regulated the social order, a university which reaffirmed that order by inculcating it through legal and theological education, and a legal system that preserved it. Given this close relationship, it is not the case that legal studies only commenced at the

4 Clavero, "Religión y derecho. Mentalidades y paradigmas", 88.

5 Tau Anzoátegui, Casuismo y sistema, 44-47 and 57-61.

6 Agüero, "Las categorías básicas de la cultura jurisdiccional", 28-29. 
University of Córdoba del Tucumán with the creation of the chair of Institutes in 1791. These studies had already begun during the Jesuit period and were not only evident in the form of lectures on ecclesiastical law that were given by the chair of canons, but also and above all in those on moral theology. The greater part of legal instruction took place at the faculty of theology through teaching on the origins of power and law, the classifications of justice, and the relationship between divine and human laws. If we wish to understand the regulatory culture of the period, we must consult not only the legal authorities and texts, but also the moral writings produced in this religious environment.

The object of this chapter is to examine the teaching at the University of Córdoba del Tucumán with a view to finding part of the answer to the question of whether the School of Salamanca can be considered a case of global knowledge production. This case study is anomalous in that the expulsion of the Jesuits from the university, who had been so closely involved in the heyday of that institution, makes one wonder whether that relationship came to an end from that moment.

In order to pursue this objective, this chapter asks whether: 1) the Córdoba professors and students were part of the School of Salamanca, understood as an "epistemic community", during the 17 th century and the first half of the 18 th century (the Jesuit phase); and 2) it is possible to formulate a late-colonial, homeland reinterpretation of the School's ideas and ways of reasoning in line with the postulates of the history of knowledge and "cultural translation".

The aim is to reveal the intellectual link between the University of Córdoba and the School of Salamanca at two different moments. To this end, we can rely on such eloquent testimonies as, for example, the dissemination of Suarismo in courses of theology, the long-standing presence of authors from the School in the library catalogue, doctrinal references in texts written by professors for the lessons on canons, and the central role of an author of the stature of Melchor Cano.

During the Jesuit period, the professors, who taught Suárez's writings in classes that were initially tailored to the need to train missionaries, read the library's probabilistic texts and wrote resolutions for specific cases were clearly part of a global "epistemic community". It was a geographically dispersed community of shared knowledge which used the same methods of reasoning and common intellectual references across several centres of production that were not necessarily of the same importance as or based solely in the city of Salamanca. ${ }^{7}$ In this epistemic community, the professors of Córdoba also

7 See chapter 1 of this volume, Duve, "The School of Salamanca. A Case of Global Knowledge Production". 
contributed to producing a legal-political language. On the one hand, their teaching of legal issues in a theological, scholastic environment on the basis of readings from Aquinas's Summa as commented by Suárez participated in a common idea of a divine order, within which other lower normative spheres could be distinguished. On the other, the fact that professors wrote their own teaching texts and made decisions regarding particular cases by recognising common places or selecting authorities, and shared a scholarly language, forms of academic communication, and common rules of behaviour ${ }^{8}$ with authors and professors from other regions, allows the School of Salamanca to be viewed as a case of global knowledge production in which the University of Córdoba formed an integral part.

The final sections of the chapter focus on another period at the University of Córdoba. The continuing link between theology and law after the foundation of the faculty of jurisprudence will be discussed and the reinterpretation of the Salmantine legal tradition in the Republican period will be explained. ${ }^{9}$ This reinterpretation pragmatically gave new meanings to old scholastic terms in a bid to justify a new covenant of political obedience in the revolutionary order. Our intention is to show how the legal-political language of the School of Salamanca was revamped to serve new purposes in those late-colonial and Republican periods.

It is necessary to first explain my use of the term "Salmantine legal tradition" in order to link it to the methodological assumptions of this work, especially to the notions of the School of Salamanca as an "epistemic community" and "cultural translation". By "Salmantine legal tradition" I refer to the way that the cultural production (doctrines, resolutions, ways of reasoning) of this community of 16 th- and 17 th-century authors eventually became a tool to create new values and norms. ${ }^{10}$ Therefore, when we talk about the "Salmantine legal tradition", we refer to the productions of that epistemic community which were given fresh meanings in another temporal context (the end of the colonial period) so that their legal-political language might serve to justify the new national order.

Our study comes to an end in 1821 with the first important reform of the curriculum by Dean Funes, which was approved shortly after the political revolution.

8 Duve, "The School of Salamanca. A Case of Global Knowledge Production".

9 For an interesting approach to understanding the legal tradition in the Iberian spaces of the 19th century with special reference to its Catholic component, see Garriga, "Prólogo", 9-18. 

Probabilism, and Canon Law. The University Library

During the university's Jesuit period, when the influence of the School of Salamanca was at its strongest, legal problems were discussed following the doctrine of Francisco Suárez, with an emphasis on moral probabilism. The foundations of law were presented theologically in accordance with the Tractatus de legibus ac Deo legislatore, where Suárez had commented on the second part of the Summa Theologiae. His Defensio Fidei was also used in order to explain the theory of political authority, in which he upheld a milder version of the famous doctrine of regicide expounded by another Jesuit, Juan de Mariana. This doctrine defended regicide in the case of tyrannical monarchs who inflicted serious harm on the community. The political pactism of scholasticism took firm root in the teaching at Córdoba, where it flourished until the second half of the 18th century, and its echo resounded when the process of independence started.

Through Suárez, probabilism also entered the university's syllabus. By adopting the Summa Theologiae for its studies, the Society of Jesus contributed to its wide diffusion throughout the Catholic world. The Jesuits were not the first or the only ones to do so, since the Dominicans were also working along similar lines, but they did analyse the text with greater freedom. Although probabilism has always been associated with the "Jesuit school", its initiator was a Dominican theologian and professor of theology at Salamanca, Bartolomé Medina (1527-1580). Medina outlined it in his Expositio in primam secundae Angelici Doctoris Divi Thomae Aquinatis and explored it more deeply in another work of 1580 entitled Breve instrucción de cómo se ha de administrar el sacramento de la penitencia. There he established one of the pillars of the doctrine by admitting the possibility of following a probable opinion in the face of a moral dilemma, even if it was in conflict with another, more likely opinion. The idea behind this reasoning was that an opinion that was supported by good reasons could be followed, even when the contrary opinion was supported by better reasons. The strong subjectivism towards which this school of thought led generated a flexible attitude towards particular problems. The resolution of doubtful moral cases required the ability to transfer abstract principles to a concrete case. This casuistry and the idea that, in uncertain cases, a less probable criterion could be applied instead of another, more likely one underlay the Jesuit reputation for a certain looseness or benignity regarding moral matters and charges of moral laxity.

The university library is testimony to the significant presence of probabilism and laxism among its volumes. There was Hermann Busembaum's Medulla 
theologiae moralis, which defended the possibility of tyrannicide; Claudio Lacroix's Theologia moralis, which was a continuation of Busembaum's work; the Resolutiones Morales by Antonio Diana; the Máximas morales by Francisco Garau; and the most obviously laxist works of Juan de Caramuel, Apologema pro doctrina de probabilitate, and Antonio de Escobar y Mendoza, Liber theologiae moralis. ${ }^{11}$ Furthermore, teachings can be found in the opinions and quotations of some professors who wrote treatises for use in their lectures. Ladislao Orosz, a Hungarian Jesuit who held important positions in the Order's province, dictated a Bulla Cruciatae tractatus for his moral theology lectures in $1734 \cdot{ }^{12}$ The treatise was rich in references to probabilistic writers like Tomás Sánchez, Villalobos, Diana, Torrecilla, Castropalao, Mendo, Lacroix, and Escobar, among others. It abounded in benign reasoning and moral flexibility.

If a thief, who offered the proceeds of a theft, has his own means with which to purchase the Bull through which he does not become insolvent to pay it back, he will profitably receive the Bull, provided that he truly intends to return the stolen goods. And the reason for this is because although, certainly, the money given for the Bull which was received was physically someone else's, it is equivalent [to being part] of the goods conferred by God to the same thief, since the thief wants to restitute his property for it and is not obliged to restitute it in the number but at the sum in kind. ${ }^{13}$

The Prosecutio tractatus de impedimentis matrimonii by the canon law professor Fabián Hidalgo was published in the same year, $1734 \cdot{ }^{14}$ References to jurists and legal texts were much more numerous than they had been in the previous work, and traces of probabilism could also be found in the quotations and conclusions. In the dispute over clandestine marriage concerning specifically the presence of the parish priest and the spouses, Hidalgo began by accepting

\footnotetext{
11 Llamosas, La literatura jurídica de Córdoba del Tucumán en el siglo XVIII, 186-188.

12 Orosz S.J., Tratado sobre la Bula de Cruzada.

13 "Un ladrón que ofreció el dinero de un robo, si además de éste tiene el propio de manera que mediante la compra de la Bula no deviene insolvente para restituirlo, recibirá útilmente la Bula con tal que verdaderamente tenga la intención de restituir lo robado. Y la razón es porque entonces, por cierto, el dinero conferido en favor de la Bula, aunque materialmente recibido sea ajeno, es equivalentemente de los bienes conferidos por Dios al mismo ladrón, puesto que el ladrón quiere restituir el suyo por aquél y no está obligado a restituirlo en el número sino a lo sumo en la especie", Orosz S.J., Tratado sobre la Bula de Cruzada, 112-113.
}

Hidalgo S.J., Tratado acerca de los impedimentos de matrimonio. 
that if they were absent, the contract was not valid, only then to argue for the opposite position, endorsed by "five doctors who seem to support Leandro del Sacramento and Gobat with the aforementioned Marín, whose foundations he does not hesitate to give, as if by chance they were thought likely". ${ }^{15}$ Together with them, he approved the possibility that the marriage was valid only with the presence of the witnesses.

In theology classrooms, the main legal texts of canon law, both general and Derecho Indiano, were also explained, and the works of some canonists were used. The Cursus iuris canonici, hispani et indici by Pedro Murillo Velarde and the ideas of Domingo Muriel, the last provincial prefect of Paraguay before the expulsion of the Jesuits, were consulted. In his Rudimenta iuris naturae et gentium, Muriel maintained the traditional lines of scholasticism in defiance of the modern representatives of the natural law school of thought, such as could be found in Grotius and Pufendorf.

As for the authors of the School of Salamanca who were known, read, and discussed at the university during the Jesuit period, the library catalogue of 1757 attests to their strong presence and influence in Cordovan studies. Although analyses of the circulation of ideas are limited if libraries are used as the only sources, such as here in the case of the university catalogue, if studied effectively, they may provide some strong hints, linked as they were to the lessons and in permanent contact with professors and students. Its holdings included central works of the School of Salamanca. One could find the famous theological relectiones of Francisco de Vitoria; almost all of Francisco Suárez's works, including his Tractatus de legibus ac Deo legislatore, which was used in the chairs of theology; the commentary on Penance by Navarrus (Doctor Martín de Azpilcueta); the classic work of positive theology by Melchor Cano, De locis theologicis; the commentary on Aquinas's Summa by Cano's disciple Domingo Báñez; the treatise De iustitia et iure by the Dominican Domingo de Soto; the extremely well-known criminal law treatise by Alfonso de Castro, $D e$ potestate legis poenalis; the history of Spain by the Jesuit Juan de Mariana; treatises and commentaries by Luis de Molina; the commentaries and disputes of the Summa by Gabriel Vázquez; and more strictly legal questions, like the various resolutions by the Salmantine Doctor Diego de Covarrubias y Leyva. ${ }^{16}$

The shared readings, the use of the same authorities, the structure of the classes, and the design of lessons under identical schemes of practical

\footnotetext{
15 “[...] cinco Doctores a los que parecen apoyar Leandro del Sacramento y Gobat junto al citado Marín, cuyos fundamentos no vacila en dar, como si por casualidad fueran pensados probables", Hidalgo S.J., Tratado acerca de los impedimentos de matrimonio, 304.

Llamosas, La literatura jurídica de Córdoba del Tucumán en el siglo XVIII, 180-184.
} 
reasoning mean that the Jesuit University of Córdoba can be safely regarded as a member of the discourse or epistemic community known as the School of Salamanca.

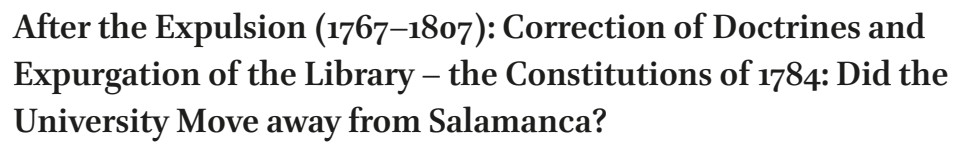

The ${ }_{1767}$ expulsion initiated a process of ideological change in which the Jesuit doctrine was uprooted and replaced by that of its critics. In Córdoba, this change was effected by granting the regency of the university to the Franciscans, in blatant contradiction of the order to give it to the secular clergy. This decision was based on the fact that the majority of the clergy had been educated by Jesuits and that Franciscans were already trained in the fight against probabilism. Worth emphasising in connection with this is the opinion of the fiscal of the Council of the Indies of 9 April 1768 which indicated the books and authors that should guide the lectures. In view of the attempt to transfer the University of Córdoba to Buenos Aires and the opposition of the Cordovans, the prosecutor ruled that it should remain in Córdoba, and

The doctrine of the expelled ones should be banished, to be replaced with that of Saint Augustine and Saint Thomas Aquinas, and positions be given to secular clerics of proven doctrine with the agreement of reverend bishops, and, if they are lacking, members of religious orders for now, who are to teach by the letter of Saint Thomas Aquinas, Cano's De Locis Theologicis, and the Teología Moral by Natal Alejandro and Daniel Concina, in order to banish the laxity of moral opinions. ${ }^{17}$

Moreover, a royal decree of March 1768 was received in Córdoba and collected in the Novisima Recopilación which encouraged the use of the Incommoda probabilismi by the Dominican Mas de Casavalls, who challenged the thesis

17 “[...] desterrar la doctrina de los expulsos, sustituyéndola por la de San Agustín y Santo Tomás, y colocando de acuerdo con los reverendos obispos, clérigos seculares de probada doctrina y en su defecto, religiosos, por ahora, que enseñen por la letra de Santo Tomás, el Cano de Locis Theologicis y la Teologia Moral de Natal Alejandro y de Daniel Concina para desterrar la laxitud de las opiniones morales", Peña, Los sistemas jurídicos en la enseñanza del derecho en la Universidad de Córdoba (1614-1807), 97. 
of tyrannicide, ${ }^{18}$ and another royal provision from the following year (1769) prohibited the university from teaching the works of the Jesuits Calatayud, Busembaum, and Cienfuegos. ${ }^{19}$ Subjected to looting after the expulsion, the library was expurgated. In November 1771, Juan José de Vértiz, the governor of Buenos Aires, sent "the laxist books of doctrine that the expelled regulars defended and taught" to the Junta de Temporalidades, ${ }^{20}$ and when the library was sent back to the university, it was made clear that works of laxist doctrine had to be separated beforehand "by learned and judicious people". ${ }^{21}$ When new volumes were purchased to refresh the collection, the Franciscans followed these directives by acquiring books by authors who were royalists in matters of policies and rigorist and anti-Jesuit in moral issues. And so, according to the testimony of the rector Pantaleón García in 1806, to "Sanchez, Fagundez, Lacroix, Vivas, and other Metaphysicians, Ascetics, and expounders" who represented the Jesuit school, ${ }^{22}$ the Franciscan regency added Tournely, Cano, Gotti, Concina, Santo Tomás, Juenin, Marca, Acevedo, Solórzano, and Natal Alejandro, among others.

It is important to study the changes that occurred in this period at the University of Cordoba in their context and that means examining them in the light of the reforms in Spain. Although the modifications at Cordoba had peculiarities of their own, the best way to gauge them is to compare them with the Spanish ones from which they clearly derived.

The Spanish reforms of Charles III were gradual, but they maintained a coherence that was lent to them by a centralising zeal and the imposition of study-texts which were rigorist with regard to morality and royalist with respect to Church-Crown relations. The guiding influence of the Salamanca Plan of 1771 as a model for change was decisive. ${ }^{23}$ The very subjects that were privileged on the curricula - practical theology, conciliar history, Church history, national councils, legislation prior to the Decretum Gratiani - were indicative of the genuine desire to promote education that favoured their positions. Of particular importance to any understanding of events at Córdoba is the principal concern that there was to introduce the study of Spanish national

\footnotetext{
18 Instituto de Estudios Americanistas, Universidad Nacional de Córdoba, Argentina (IEA), Fondo documental. Documento 6751.

19 IEA, Fondo documental. Documento 6627.

$20 \quad$ IEA, Fondo documental. Documento 2616.

21 IEA, Fondo documental. Documento 2629.

22 "Sanchez, Fagundez, Lacroix, Vivas, y otros Metaphisicos, Asceticos y espositores", cited by Cabrera, "La antigua biblioteca jesuítica de Córdoba", 184-185.

23 Peset and Peset, El reformismo de Carlos III y la Universidad de Salamanca.
} 
law in the law faculties, and to that end texts of Roman law were used for comparative purposes in the bachelor's degree, while first-hand study of national laws was required for the licentiate degree.

During the Franciscan period, the university changed from an institution whose rector and professors were appointed by the provincials of the Society of Jesus with no intervention from the civil authorities to one that was firmly under the control of royal authorities. Once teaching recommenced and the regency was entrusted to the Franciscans, the appointment of the rector and professors became the duty of governors and viceroys in their role as vicepatrons. This change is a clear reflection of Bourbon interventionist policies in the universities, embodied in the reforms of 1771 .

Something of the University of Córdoba's ideological environment can be glimpsed from the changes made by the bishop of Tucumán, José de San Alberto, to the constitutions in 1784 . At the end of 1783 , the viceroy of Río de la Plata, Juan José de Vértiz, commissioned San Alberto to visit the university at the request of the rector, Pedro Parras. After listening to suggestions from the cloisters, San Alberto drafted new constitutions on the basis of the previous ones of 1664 and submitted them to the new viceroy, the Marquis of Loreto, for appraisal in April 1784. San Alberto was a royalist and anti-Jesuit who defended the doctrine of the divine right of kings under the influence of the French theologian Jacques-Bénigne Bossuet. Analysis of San Alberto's Constitutions reveals his legal and political ideas. His intention to legally replace Jesuit doctrine was clear in his proposal to pursue a "compendium of healthier morals" in theology. Another reference appeared in the section dealing with solemnities and academic events, where it was stipulated that when conferring degrees, the university secretary had to take an oath "to defend the Immaculate Conception of Mary Most Holy; to attend certain functions of the university; to challenge, and detest the doctrine of tyrannicide and regicide; to obey the rector of the university [...]". This oath, which embraced the condemnation of the Council of Constance of 1415 of the proposition concerning tyrannicide, largely reproduced one that was already taken at the institution. Finally, the constitution 93 hinted at the theological orientation of the curriculum and confirmed the lines of thought that were propagated during the Franciscan regency.

For the faculty of arts, San Alberto requested the same books that were used at the Universities of Salamanca and Alcalá de Henares at the time; for theological studies, he was more specific, giving precise names of authors "and likewise the compendia of Gonet for theology, or the Summa of Saint Thomas Aquinas, and, for the study of morals, the compendia of Concina, Echarri, Kiclet, Ferrer, or Lárraga, who were all enlightened in recent years and brought to a 
sound doctrine that is safe in all its parts". ${ }^{24}$ The predominance of Dominican writers was clear: four on his list (St. Thomas Aquinas, Juan Bautista Gonet, Daniel Concina, and Francisco Lárraga) belonged to the order. Unsurprisingly, the central figure for the study of moral theology was Daniel Concina. What all these books, which marked the orientation of the morality mandated by Bishop San Alberto and confirmed the path followed since the expulsion of the Jesuits, had in common was that they were recent ("all enlightened in recent years"), condemned probabilism, and, to a greater or lesser extent, ascribed to moral rigorism. ${ }^{25}$

If discussions about "moral systems" were of secondary importance at other universities, at Córdoba they were fundamental, since they involved the complete reorganisation of studies and a radical ideological transformation. Students of moral theology could not have failed to notice that environment after the expulsion of the Jesuits, and we may assume that although their "legal education" had been prepared since joining the order, their passage through the university significantly marked them, whether in the way they argued and resolved doubtful cases when faced with multiple answers or in the way they viewed the relationship between subjects and their monarch. In San Alberto's Constitutions a political rationale or orientation that was not alien to the interests of the government could be detected in its explicit objectives, in the subjects prescribed for study, in the manner of teaching them, and in the set authors. The abandonment of scholastic pactism in, for example, the form of the theoretical explanation of the origin and exercise of the powers, implied a shift away from Suarist ideas although, as we shall see, that shift was not final.

In 1791, the royalist environment of the Franciscan regency was the background to the birth of autonomous legal studies. Victorino Rodríguez, the first professor of Institutes, taught the political principles of enlightened despotism following the ideas of Bossuet and royal law, which was compared with Roman law with the aid of the work of the Dutch humanist Arnold Vinnius. The main goal was to introduce the study of the law of the kingdom. As Viceroy Arredondo's Auto said,

[The professor] will be obliged to explain the text of Justinian's Institutes with Arnold Vinnius's commentary, noting their concordances or

24 "Y asi mismo los compendios de Gonet para la Theologia, ó la suma de Sto. Thomas; y para el Moral los compendios de Concina, Echarri, Kiclet, Ferrer ó Larraga ilustrados todos en estos ultimos años, y reducidos á una doctrina sana, y segura en todas sus partes".

25 Llamosas, "Las ideas jurídicas universitarias en Córdoba del Tucumán: las Constituciones de San Alberto de 1784", 1256-1258. 
disagreements with our royal law, so that the students will certainly be trained in the former, which is the only one that rules and governs us in temporal matters. ${ }^{26}$

Royal law was studied in a hands-on manner in the licentiate, and to obtain the degree, one had to find a few points of the Laws of Toro in the commentary of the famous jurist Antonio Gómez.

Vinnius's In quatuor Institutionum Imperialium commentarius academicus et forenses fulfilled an important role. While not a synoptic manual like those already used at the time, it was part of a student-oriented genre which resorted to logic and dialectic in order to conceptualise and establish partitions and classifications. Vinnius was a representative of late legal humanism, and even though at first glance it appeared that the criticisms and modes of legal production of that school of thought were part and parcel of Vinnius's text, it was used with quite another purpose. The work did introduce the ideas of legal humanism, but they had already lost their force since the star of that school of thought had waned. Its principal function at the University of Córdoba was, as in Spain, to provide access to the study of national laws and allow for them to be gradually related to Roman law. But there was one complicating circumstance: 20 years before the creation of the chair of Institutes, the Instituciones del derecho civil de Castilla [Institutions of the Civil Law of Castile] by Asso and Manuel had already been available and had started to replace books like Vinnius's in Spain. However, the text of the Dutch humanist enjoyed a long life at Córdoba, where it would survive in the lecture room until the transfer of the university to the secular clergy and the reforms of Dean Funes.

In this later period, that law and theology were still thought of as related orders of knowledge is demonstrated by the fact that it was compulsory for law students to attend lectures on morals and canons at the theology faculty. A new chair of canonical jurisprudence was created in 1793, alongside the pre-existing ones, to teach ecclesiastical and other institutions, such as marriage and family, which were regarded as part of natural law. Once again, as was the case with the Spanish curricula, this orientation was favourable to the Crown. ${ }^{27}$

26 “[...] estará obligado a explicar el texto de las Instituciones de Justiniano con el comentario de Arnol de Vinnio advirtiendo de paso las concordancias o discordancias que tengan con nuestro derecho real, para que desde luego vayan los estudiantes instruyéndose en éste, que es el único, que en materias temporales nos rige y gobierna".

27 Peña, Los sistemas jurídicos en la enseñanza del derecho en la Universidad de Córdoba (1614-1807), 182-183. 
As for political and legal ideas, expressive of the trends disseminated from the chair of the Institutes were the Conclusions defended by Jerónimo de Salguero y Cabrera in 1793. Salguero y Cabrera, a former student of Victorino Rodríguez, was a Franciscan-educated teacher of arts who had to formulate his arguments in accordance with the constitutions in force. Dedicated to Bishop Moscoso, his Conclusions were firmly in the royalist camp. Relying on the authority of Bossuet, Salguero y Cabrera staunchly contested regicide and upheld the theory of the divine right of kings, according to which royal authority derived directly from God. ${ }^{28}$

\section{The Times of Dean Funes (1808-1821) - Melchor Cano's Book - Derecho Patrio, Natural Law, and Law of Nations - The Defensive Closure of Dogmatic Theology}

The public service career of Dean Gregorio Funes (1749-1829) spanned the late colonial period and independence, Córdoba and Buenos Aires. The record testifying to his ideas from both periods is eloquent of his pragmatism. It is not surprising that in Córdoba the Funes of 1789 sang the praises of the reformist monarchy in his Oración Fúnebre [Funeral Prayer] to Charles III, while in his Oración Patriótica [Patriotic Prayer] that was delivered in the cathedral of Buenos Aires, the Funes of 1814 denounced Bourbon decadence in justification of breaking colonial bonds. ${ }^{29}$ Funes was a student of the Jesuits at Córdoba faculty of arts, he obtained his doctorate in theology during the Franciscan regency, and he held a bachelor's degree in both laws from the University of Alcalá de Henares. He then served as a lawyer on the royal councils in 1779, became a dean of the cathedral of Córdoba in 1804, and was made rector of the university when it was given over to the secular clergy where his legacy lies in the reforms he made to the university curricula. Moving into ever higher positions, he was a member of the Constituent Congress that drafted the centralist constitution of 1819 , a senator, by virtue of that constitution, for the Ecclesiastical Chapter of Buenos Aires, and a representative before the governments of Colombia and Bolivia. Funes is a central figure for a study like this one because he took part in and shaped the transition from the old political order to the new and gave its foundations their moral and legal justification.

28 Peña, "Conclusiones jurídicas defendidas en la Universidad de Córdoba a fines del siglo XVIII", 11.

29 Llamosas, "Vos das los imperios, vos los quitas: el deán Funes y su oración fúnebre a Carlos III (1789)". 
In April 1815, almost five years after the political revolution that ended the Viceroyalty of Río de la Plata, the cloister of the University of Córdoba put into effect a new curriculum that had been written by Gregorio Funes. The curriculum, which had taken a long time to take formulate, was rooted in the changes that occurred in the University of Córdoba in the later years of the colonial period. Undoubtedly, the curriculum was more indebted to the royal decree issued by Charles IV on 1 December 1800 than to the May revolution of 1810 , and it was not executed until late 1807 by the Viceroy Liniers, who created the Royal University of San Carlos and Our Lady of Monserrat and put an end to a long dispute between Franciscans and seculars over the control of the corporation..$^{30}$ The end of the Franciscan government and the new leadership of the secular Cordovan clergy allowed for the rise of Dean Funes, who was appointed rector in January 1808.

No sooner had he been appointed, Funes started work on a provisional curriculum for immediate implementation, which he expected to complete in a short time. The curriculum of 1808 was never formally approved, but to judge from examination certificates and references made to it by members of the cloister, it was used and effective. Despite its temporary nature, the curriculum was in force for seven years, ${ }^{31}$ although in spirit, it was effective for far longer because the final curriculum of 1815 preserved its central lines.

A royal decree of 1800 ordered the creation of three chairs of scholastic theology and one of morals for the theology faculty. Theological instruction was preceded by a compulsory course at the arts faculty on Melchor Cano's De locis theologicis. At the end of the 18th century, the famous 16th-century Dominican of Salamanca was considered an opponent of the Society of Jesus and a supporter of royal interests. In times prone to royalism and moral Jansenism, Cano's former criticisms of the doctrines of the Jesuits were put to new uses, and his book of positive theology - which was historically aware and made critical use of the sources of theological knowledge - was reinterpreted in line with the interests of Bourbon reformism vis-à-vis the teaching of theology. We have already seen how the university acquired Cano's work for its library in the process of replacing Jesuit probabilism and strengthening royalism. Its use in the faculty of arts from 1808 as a core, preliminary course prior to starting major studies in theology also makes plain the influence of Spanish university reforms at Córdoba and the practical re-use of one of the main authors

30 On the dispute between the Franciscans and the secular clergy, see Benito Moya, Reformismo e Ilustración. Los Borbones en la Universidad de Córdoba, 57-93.

31 Luque Colombres, "El primer Plan de Estudios de la Real Universidad de San Carlos de Córdoba. $1808-1815 "$. 
from the School of Salamanca. This transposition of Cano's ideas at the beginning of the 19th century was a foreshadowing of what was to come a few years later with the advent of scholastic pactism. New interests, new practical uses indicate that these procedures for ideological readjustment and adaptation occured not only across different geographical spaces but also different time periods.

In order to obtain a bachelor's degree, the course in theology was followed by four years of scholastic theology, in which parts of Aquinas's Summa were taught with the commentary of the Dominican Billuart. Fifth-year moral theology was taught from the text of Wigandt, which was soon replaced by that of Antoine, and a sixth year, comprising Holy Scriptures - first from the works of Wigandt and then from the books of Graveson - and councils, had to be taken to obtain the degree. The authors used to teach morality were undoubtedly contrary to probabilism. The novelty of this theology faculty was that the study of canons was moved to the law faculty. The faculty of law had two chairs of civil jurisprudence (Institutes and royal law) and one of canons. Studies began with moral philosophy, a preliminary, obligatory course that was taken in the faculty of arts, which was followed by two years of the Institutes that were compared with Spanish law following the work of Vinnius, then a further two years of canonical institutions according to Berardi, who was later replaced by Selvaggio. At this point, a bachelor's degree was obtained by submitting the previa. For the licentiate degree, one had to study the Laws of Toro with the comments of Antonio Gómez during a fifth year, and in order to obtain a doctorate, students had to study Concilies and pass the Ignaciana. ${ }^{32}$ The Institutiones Juris Ecclesiastici by the Italian Carlo Sebastiano Berardi (1719-1768) was used to teach canons. Clearly royalist, they offered a faithful reflection of the initial interest of the Crown in modifying the curricula, thereby strengthening their own royal prerogatives. $^{33}$

This provisional curriculum remained in place until 1815. The first noteworthy feature is that there were no ideological changes with respect to the previous period: royalism, rigorism, and philo-Jansenism survived, showing that both Franciscans and the secular clergy agreed with the interests of Bourbon reformism and that the dispute over who controlled the university was a matter not of ideas, but of who should occupy a position of privilege in colonial

32 Luque Colombres, "El primer Plan de Estudios de la Real Universidad de San Carlos de Córdoba, 1808-1815", 24-30.

33 Llamosas, "La enseñanza canónica en la Universidad de Córdoba del Tucumán en vísperas de la emancipación: el episcopalismo de Berardi”. 
Córdoba. The school of thought had already been switched on the expulsion of the Jesuits, and those lines were maintained in 1808 . The most direct influences on the curriculum were the reforms of Charles III, especially those of Salamanca in 1771 and Alcalá de Henares in 1772.

A few years later, after the political revolution, Funes again proposed curricular reforms, this time to accompany the incipient process of independence. He explained that "the great revolution the State has suffered should impact on this kind of work and make it experience its own vicissitudes. A literary education under an absolutist government cannot function under a free constitution" ${ }^{34}$ These words presaged a curriculum which was novel, mould-breaking and, in some respects, modern. Funes himself justified the study of natural law and the law of nations in unequivocal terms of rupture from the colonial order, "It is not possible for members of a sovereign people, who have devoted themselves to other sciences, to ignore the rights of the citizen and those that correspond to the body of their Nation".35 And in relation to the need to study recent, national legislation, he said "Our Revolution has brought about the expiry of the laws that the kings of Spain gave for the Americas. From now on we will no longer keep these laws except as a monument of the degradation in which we have lived". ${ }^{36}$

For the study of scholastic theology, Funes did not maintain, as he had in 1808 , his inclination for Billuart but stated that, "in so far as it will be difficult for the time being to collect a sufficient number of copies of the others, a start can be made with the Lyonnais". ${ }^{37} \mathrm{He}$ was referring to Institutiones theologicae auctoritate D. D. Archiepiscopi Lugdunensis ad usum scholarum suae diocesis editae by the Oratorian José Valla. Published in 1780, it had been commissioned

34 "La grande revolución que ha sufrido el Estado, debía influir en este género de trabajo y hacerle experimentar sus mismas vicisitudes. Un plan de educación literaria bajo un gobierno absoluto, no podía convenir bajo una constitución libre", Martínez Paz, "Prólogo", 10.

35 "No es posible que los que son miembros de un pueblo soberano, cuando se dedican a otras ciencias ignoren los derechos del ciudadano y los que corresponden al cuerpo de su Nación. Que los ignoren en las monarquías, donde reconcentrados todos los poderes en un solo hombre no le queda al vasallo otro derecho que para temer y obedecer, pase, esta es la condición de los buenos esclavos; pero en las repúblicas y gobiernos libres como el nuestro no puede ser permitida a ningún hombre de letras esa ignorancia", Papeles del deán Gregorio Funes, 6o.

36 "Nuestra Revolución ha hecho caducar las leyes que dieron los reyes de España para las Américas. En adelante ya no conservaremos estas leyes sino como un monumento de la degradación en que hemos vivido", Papeles del deán Gregorio Funes, 66.

“[...] por cuanto será difícil acopiar por ahora de las otras suficiente número de ejemplares, puede darse principio por el Lugdunense", Papeles del deán Gregorio Funes, 55. 
by the archbishop of Lyon for the seminary and the university, and Valla owed his name to that French city. Its detractors pointed out its anti-Roman character, its "maxims against the Apostolic See", ${ }^{38}$ and the authority it granted to the councils.

The second year of theological studies was dedicated to dogmatic theology. The choice of authors and the subject's foundations, as set out in the curriculum, constituted a manifesto against political modernity. Funes criticised at length the philosophy that sought to "put out the torch of Revelation" and disseminated atheism and deism, and the thinkers who had left man free to the instinct of his senses and tried "to annihilate the immutable dogmas of Christianity". The adjectives used were eloquent and direct: the new doctrines were "monstrous", "pestilent", and "degrade[d] man to the condition of the beasts". Faced with these unpalatable ideas, Dean Funes had no choice but to propose a powerful remedy. The most widespread and elementary theologians were not enough. A work was required that, with "choice scholarship, strong and luminous discussion", would demolish the arguments that enabled the triumph of "the Hobbeses, the Spinozas, the Rousseaus, the Hélvetiuses, and the Voltaires". ${ }^{39}$ The function of dogmatic theology was to serve as a bulwark against new ideas. The proposed book was De fundamentis religionis et de fontibus impietatis by Antonino Valsecchi (1708-1791), a professor at Padua. ${ }^{40}$ This work was part of the extensive literature that appeared in Europe as a reaction to the Enlightenment, and its purpose was to refute rationalism (Rousseau was one of the chosen enemies) and its attempt to confine religion within the limits of natural reason. ${ }^{41}$

Although Funes struck a balance when writing about the teaching of morals and criticised rigorism and laxism alike, ${ }^{42}$ when it came to selecting a text, he relied on the authority of Benedict XIV, who had sent him to the Collegio di Propaganda Fide, and opted for Antoine's book. Antoine's Jesuit status should not deceive us: his Theologia moralis was openly opposed to probabilism and

\footnotetext{
$38 \quad$ Papeles del deán Gregorio Funes, 254.

39 "[...] los Hoveses, los Espinosas, los Rusoes, los Elbecios, y los Voltaires".

40 Valsecchi, De los fundamentos de la religión y de las fuentes de la impiedad.

41 For a more extensive analysis of some passages of Valsecchi's book, see Vera Urbano, "La libertad religiosa en el pensamiento católico según los tratados de teología moral y la literatura polémica del siglo XVIII", 445-474.

42 "If teaching lax opinions is to introduce relaxation, teaching too narrow opinions is to impose a yoke, which has not been imposed by the Gospel" ["Si enseñar opiniones laxas es introducir la relajación, enseñar opiniones demasiadamente estrechas es imponer un yugo, que no ha impuesto el Evangelio"], Papeles del deán Gregorio Funes, 57.
} 
recommended the adoption of rigid positions when confronted with dilemmas of conscience.

I have left an examination of natural law and the law of nations, which were proposed for free-time study during the final two years, to the end because their inclusion has been the basis of the view that the curriculum was modern and mould-breaking. These subjects, together with rhetoric, were commonly taken by students of theology and jurisprudence, who attended the same classes together. We have already seen how the author of the curriculum took it upon himself to highlight the novelty and importance of natural law and the law of nations for the new order, declaring that no member of a sovereign people should be unaware of them. To this end Dean Funes recommended the reading of Hugo Grotius (1583-1645) and Samuel Puffendorf (1632-1694) in the summary of Johann Gottlieb Heineccius (1681-1741). This was not entirely novel, but can it be interpreted in a completely modern key, separate or "forgetful" of what Funes had proposed for dogmatic theology?

For the faculty of jurisprudence, Funes preserved what had been Cordovan tradition, derived from Spanish universities, since the creation of the Institute's chair by the Franciscans, namely, the use of a manual of Institutions, in other words, Vinnius's book.

When choosing an author for teaching canon law, Dean Funes tried to be balanced and thought that both the ultramontanes and the ultra-royalists should be discarded. Although he still considered that Berardi, chosen in 1808, was to be "highly recommended", he programmed the work of another Italian, Institutionum canonicarum by Giovanni Devoti (1744-1820), a professor at the College of Sapienza. Funes's argument was that Devoti's books were easier to obtain, but the Italian was sympathetic to papal centralism to the point that some considered him an "ultramontane".

As for the teaching of the law following the political revolution, even though the curriculum hoped to propose the study of autochthonous laws to the exclusion of royal law, there was as yet little new legislation, so it was insufficient to fill a whole year's instruction. No evidence of any examinations have been found, but there were still references to the Laws of Toro, which had to be passed using the commentary of Antonio Gómez to obtain a licentiate. ${ }^{43}$

43 Archivo General e Histórico de la Universidad Nacional de Córdoba, Argentina (AG HUNC), Libro de Exámenes de Derecho (1791-1841). Año 1816, f. 29 r; Año 1817, f. 3 o r. 


\section{$5 \quad$ Retreat to Religion: New Justifications with Old Materials (A Reinterpretation of the Salmantine Tradition)}

The University of Córdoba swung from Suarist political pactism to Bossuet's divine right of kings, from the probabilism of the Jesuits to the moral rigorism of the Franciscans. In keeping with the intentions of Bourbon reformism, the university appeared to witness the abandonment of the traditions and the political language which had predominated until the mid-18th century. However, what happened in the late colonial period and at the beginning of the independence period was a reinterpretation of that tradition and language, and it is here that a link can be forged between the university and the School of Salamanca. In fact, those intellectual manoeuvres had never actually ceased. We have seen how Cano's De locis theologicis was still being used in the early 19th century after being re-styled as an "anti-Jesuit" understanding in a context of moral rigorism. The doctrine of political pactism underwent a similar process

Dean Funes, whose initial education had been at the hands of the Jesuits, saw how the world he knew was disintegrating and decided to participate in the construction of a new one that would end up being not so very different from the old one. To this end, he took pains to ensure that the revolutionary reforms steered clear of radicalism and found moderate outlets. Faced with the prospect of anarchy and disorder that could be glimpsed from the ideas of Enlightened radicalism, Funes staked a claim for the tried and trusted security of the old Catholic order. His efforts were intended to reconcile the May Revolution with Christian doctrine by justifying the former as a means of defending religion. Funes could brook political change for more or less practical reasons, but in no way did he expect it to bring about changes in society.

As an ecclesiastic educated at the Franciscan University of Córdoba and the reformed University of Alcalá de Henares, the dean of the colony remained loyal to the most basic principles of the world he knew in times of turmoil: a hierarchical society, a Catholic constitution, and a fear of disorder. In order to justify changes to the political order which left the social order stable and intact, Funes had to dust down scholastic pactism and the notion of the noncompliance of obligations by one of the parties. Another leading figure of the same period, the former rector during the Franciscan period, Pantaleón García, followed a similar policy.

Other evidence corroborates this line of action at the university in the early years of nationalism. In 1813, before the curriculum took effect, José Felipe Funes, the dean's nephew and chair of Institutes, inaugurated the academic 
year with a discurso on the teaching of jurisprudence. His third point was a crystalline statement of a legal conception of the ancien régime in which the origin, foundation, and purpose of the law could not be human because it first derived from religious phenomena unavailable to men. The object of legislation was "to establish and preserve the external order of society", while religion was already in charge of "strengthening its internal order" and serving as its foundations. The law existed to guarantee the preservation of an order that was already given and which alone could be preserved because it came from nature. José Felipe Funes used the well-known definition of justice from the Digest, ${ }^{44}$ a notion which, he emphasised, when infused by God sought to preserve the "preeminent rights of His omnipotence and of the greater powers that represent Him". ${ }^{5}$ There was no doubt that human powers bore the stamp of divine authority, and the relationship in which José Felipe Funes found a model was the family, as was typical of the ancien régime, where power-relations were predicated on subordination. The conjugal bond and filial subordination made up "the primitive prototype of other societies which we call peoples, republics, kingdoms, and empires". ${ }^{46}$ Point 18 of the Discurso is another that might give an erroneous impression of modernity if read hastily. Entitled "Fundamentos de la sociedad, la libertad, la necesidad y los pactos" [Foundations of society, liberty, need, and agreements], José Felipe Funes explained that the peoples, republics, kingdoms, and empires, "these social colossi", had their support in the freedom and needs of men. For José Felipe Funes, freedom "loses something" when society is constituted "by means of pacts as reciprocal as inviolable [...] but it is nothing in comparison with what it gains" ${ }^{47}$ Freedom was submitted through the "General Will" to a "Sovereign Owner or Supreme Body", to ultimately enjoy happiness through these agreements. Although Funes recognised that some public figures opposed pacts, his view was that reason was on the side of pactism. In the following point, he declared that positive law was "sanctioned with the Supreme Authority of the Nation". ${ }^{48}$ These contractarian expressions, references to the "General Will" and the "Nation" sanctioning the norm, together with the notion of jurisprudence as the science that "teaches the rights of men", have a modern ring that

44 Justitia est constant et perpetua voluntas suum cuique tribuendi. [Justice is the constant and perpetual wish of giving to each his due.]

45 "Preeminentes derechos de su omnipotencia y de las mayores Potestades que lo representan".

46 IEA, Fondo documental. Documento 6647. Punto 17.

47 IEA, Fondo documental. Documento 6647. Punto 18.

48 IEA, Fondo documental. Documento 6647. Punto 19. 
might tempt us to detect the exclusive influence of Rousseau on the author. However, there are numerous examples of the self-serving use of these phrases in similar cases ${ }^{49}$ and they should be understood not in isolation, but in the general framework of an argument that was clearly traditionalist. In point 32 , a passage dealing with positive law states that this "is prepared with the discussions of the learned" and "is seasoned with the vote of prudent men", 50 before finally receiving the sanction of the nation's supreme authority, whereupon it is established as the "expression of that Supreme Will". Worthy of note are the contradictory notions of the vote of prudent men in the preparation of the law and of the law as an expression of the will of the nation. Leaving Funes's references to Rousseau to one side, the traditional character of his argumentation and his pragmatic reinterpretation of Salmantine scholasticism came to the fore when he set out the reasons why the war of independence against Spain was justified. He pointed out the various criticisms of the conquest - Spanish covetousness and the cultural decadence of the Indies - in order to support the breakdown of the colonial pact and the resumption of natural law by forming their own government.

The revolution did not separate the University of Córdoba from its intellectual heritage but generated new arguments for adapting to the changes of the political order. Many of them were grounded on the old doctrines enshrined in the Salmantine tradition, pactism being a case in point. The members of the university community did what they could to prevent novel political events from leading to sudden social change, as is attested collectively by the Discurso, the 1815 curriculum, and the Oraciones of Pantaleón García. After the revolution, the university formulated a coherent discourse which accepted the new political order by retreating into religion. This meant justifying the rupture of the colonial pact, even if that went against its previous teachings, but it also meant defending the traditional social order and saving it from innovation. Merely defending political freedom was clearly no symptom of modernity, although many have attempted to forge such a link. A great deal of evidence suggests that independence could be justified perfectly well by drawing on traditional intellectual sources.

The moral rigorism which had characterised theological teaching at Córdoba since the expulsion of the Jesuits persisted during this stage. It was a doctrine that helped maintain respect for whichever authorities might happen to be in power by ruling out the possibility of disobedience or taking a

\footnotetext{
49 See Dean Funes's example in Llamosas, "Vos das los imperios, vos los quitas: el deán Funes y su oración fúnebre a Carlos III (1789)".

"Se sazona con el voto de los varones prudentes".
} 
flexible approach to the laws in any particular case. It could in fact be argued that, thanks to the royalist and rigorist doctrines that were taught during the Franciscan regency, Córdoba's students were paradoxically already prepared to assimilate the new government. Thus the oaths graduates took before the new authorities may be better understood as expressing a solid pragmatism and viewed within the intellectual framework of moral doctrines based on religion which demanded the obedience of the good Christian to the authorities in any circumstances. Where oaths had once spoken of the "king" and "viceroy", they now invoked the "junta" or "assembly" without falling into any contradiction. The patriotic oath had obvious colonial roots in its religious filiation and the religious nature of the obedience it demanded, ${ }^{51}$ thereby demonstrating the continuity of a certain social worldview. The authority to which allegiance was sworn might vary, but it was still pledged on the Immaculate Conception of the Virgin Mary. What changed was the recipient, not the paradigm. Old oaths were no obstacle to proclaiming new loyalty to the governments of the homeland. There was no need for the doctrinal sources of justification to be greatly modified. The same traditional thought, rooted in scholasticism, ensured that the oath was binding as long as the conditions of the pact to which it was annexed were maintained. If one of the parties failed, its binding force was lost. This explains the virulent criticism of Spanish colonisation and the Bourbon dynasty: it was the prerequisite of abandoning the colonial pact without falling into the perjury entailed by not complying with what had been sworn. A clear case of this procedure is to be found in the 1814 Oración patriótica by Pantaleón García, the last rector of the university's Franciscan period. This defender of the divine right of kings in the colonial period had no need to embrace the Enlightenment before supporting the governments of the revolution: it was enough to recover the tradition of scholastic pactism and accuse Spain of not having met its obligations. ${ }^{52}$

Therefore, we have old ideas in a new political context: the Salamancan tradition reinterpreted in the heat of the revolution, scholastic political pactism as a justification of the new authorities and as a guarantee against Enlightenment radicalism. Although it might be considered that late-colonial Spanish American society prepared the intellectual bases for political change in a modern sense, the sources - and Córdoba was no exception - show that universities churned out pragmatists who knew how to mix doctrines and readapt them to local realities. As part of that process, the evocation and transposition

\footnotetext{
51 Lorente, "El juramento constitucional", 115.

52 Llamosas, "Rector de Antiguo Régimen, orador de la Revolución: fray Pantaleón García, un franciscano entre dos tiempos", 563 .
} 
of doctrines and ways of reasoning typical of the School of Salamanca in other times played a fundamental role.

Once the Eurocentric vision of ideas spreading from Salamanca to the rest of the world is set aside, and on the assumption that global intercommunication and common cultural praxis took place in different regions at the same time, ${ }^{53}$ the School of Salamanca can legitimately be defined as an "epistemic community" in which the University of Córdoba assuredly took part during its Jesuit period.

On the other hand, from the perspectives of "cultural translation" and a history of knowledge that aims to "write a history of the production of legal knowledge" which must consider the rules and particularities of that production, ${ }^{54}$ we can reflect on how a legal-political language was created in late-colonial Latin American on the basis of an earlier counterpart that was developed by the School of Salamanca in the 16th and 17th centuries. This opens up the possibility that, in the former colonies of the Catholic Monarchy on the eve of independence, a new discursive community evolved to justify that independence with the aid of elements deriving from the older discourse of the School of Salamanca. If the translation of normative information occurs not only in places separated by great distances, but also between different eras, education in late-colonial Cordoba constitutes an empirical case study that enables the School of Salamanca to be understood not only as a global phenomenon, but also as a re-signified phenomenon that transcends time.

\section{Bibliography}

\section{Manuscripts}

Archivo General e Histórico de la Universidad Nacional de Córdoba, Argentina (AG HUNC), Libro de Exámenes de Derecho (1791-1841). Año 1816; Año 1817.

Instituto de Estudios Americanistas, Universidad Nacional de Córdoba, Argentina (IEA), Fondo Documental, Docs. 2616; 2629; 6627;6751.

\section{Printed Sources}

Funes, Gregorio, Papeles del deán Gregorio Funes. Plan de Estudios para la Universidad Mayor de Córdoba por el Dr. Gregorio Funes. Córdoba. Año 1813, ed. by Martínez Paz, Enrique, Buenos Aires 1940.

\footnotetext{
53 See chapter 1 of this volume: Duve, "The School of Salamanca. A Case of Global Knowledge Production".

Duve, "The School of Salamanca. A Case of Global Knowledge Production".
} 
Fabián, Hidalgo S.J., Tratado acerca de los impedimentos de matrimonio (Córdoba 1734), ed. Benito Moya, Silvano and Guillermo De Santis, Córdoba (Argentina) 2005.

Index Librorum Bibliothecae Collegii Maximi. Edición crítica, filológicay biobibliográfica, ed. Fraschini, Alfredo, Córdoba (Argentina) 2005.

Ladislao, Orosz S.J., Tratado sobre la Bula de Cruzada (Córdoba 1734), ed. Astrada, Estela and Julieta Consigli, Córdoba (Argentina) 2002.

Valsecchi, Antonio, De los fundamentos de la religión y de las fuentes de la impiedad, ed. Represa y Salas, Francisco Javier de, Valladolid 1777: Real Chancillería de Valladolid.

\section{Literature}

Agüero, Alejandro, "Las categorías básicas de la cultura jurisdiccional", in Lorente, Marta (coord.), De justicia de jueces a justicia de leyes: hacia la España de 1870, Cuadernos de DerechoJudicial VI, Madrid 2006.

Benito Moya, Silvano, Reformismo e Ilustración. Los Borbones en la Universidad de Córdoba, Córdoba 2000.

Cabrera, Pablo, "La antigua biblioteca jesuítica de Córdoba", in Revista de la UNC 17 (1930), 175-216.

Clavero, Bartolomé, "Religión y derecho. Mentalidades y paradigmas" in Historia, Instituciones, Documentos 11 (1984), 67-92.

Duve, Thomas, "The School of Salamanca. A Case of Global Knowledge Production", in Duve, Thomas, José Luis Egío García and Christiane Birr (eds.), The School of Salamanca: A Case of Global Knowledge Production, Leiden / Boston 2020.

Garriga, Carlos, "Prólogo", in Agüero, Alejandro, Andrea Slemian and Rafael Diego-Fernández Sotelo (coords.), Jurisdicciones, soberanías, administraciones. Configuración de los espacios políticos en la construcción de los Estados nacionales en Iberoamérica, Córdoba 2018, 9-18.

Hespanha, António Manuel, Panorama histórico da cultura jurídica europeia, Lisboa 1997.

Llamosas, Esteban, "Las ideas jurídicas universitarias en Córdoba del Tucumán: las Constituciones de San Alberto de 1784", in Torres Aguilar, Manuel (coord.), Actas del XV Congreso del Instituto Internacional de Historia del Derecho Indiano, Vol. II , 2 vols., Córdoba (España) 2005, 1241-1263.

Llamosas, Esteban, La literatura jurídica de Córdoba del Tucumán en el siglo XVIII. Bibliotecas corporativas y privadas. Libros ausentes. Libros prohibidos, Córdoba (Argentina) 2008.

Llamosas, Esteban, "La enseñanza canónica en la Universidad de Córdoba del Tucumán en vísperas de la emancipación: el episcopalismo de Berardi”, in Guzmán Brito, Alejandro (coord.), El Derecho de las Indias Occidentales y su pervivencia en los derechos patrios de América, Actas del XVI Congreso del Instituto Internacional de Historia del Derecho Indiano, Vol. II, 2 vols., Valparaíso (Chile) 2010, 89-103. 
Llamosas, Esteban, “Vos das los imperios, vos los quitas: el deán Funes y su oración fúnebre a Carlos III (1789)", in Revista de Historia del Derecho 39 (2010).

Llamosas, Esteban, "Rector de Antiguo Régimen, orador de la Revolución: fray Pantaleón García, un franciscano entre dos tiempos”, in Salazar Andreu, Juan Pablo and Guillermo Nares Rodríguez (coordinadores), Memoria del XVII Congreso del Instituto Internacional de Historia del Derecho Indiano, Puebla (México) 2011, $533-563$.

Lorente, Marta, "El juramento constitucional", in Garriga, Carlos and Marta Lorente, Cádiz 1812. La constitución jurisdiccional, Madrid 2007, 73-118.

Luque Colombres, Carlos, "El primer Plan de Estudios de la Real Universidad de San Carlos de Córdoba. 1808-1815”, in Cuadernos de Historia 13 (1945), 11-45.

Martínez Paz, Enrique, "Prólogo", in Papeles del deán Gregorio Funes. Plan de Estudios para la Universidad Mayor de Córdoba por el Dr. Gregorio Funes. Córdoba. Año 1813, Buenos Aires 1940.

Peña, Roberto, "Conclusiones jurídicas defendidas en la Universidad de Córdoba a fines del siglo XVIII", in Cuadernos de Historia 17 (1952), 1-38.

Peña, Roberto, Los sistemas jurídicos en la enseñanza del derecho en la Universidad de Córdoba (1614-1807), Córdoba (Argentina) 1986.

Peset, José Luis and Mariano Peset, El reformismo de Carlos III y la Universidad de Salamanca, Salamanca 1969 .

Rodríguez Cruz, Águeda, Salmantica docet: la proyección de la Universidad de Salamanca en Hispanoamérica, Vol. 1, 2 vols., Salamanca 1977.

Tau Anzoátegui, Víctor, Casuismo y sistema, Buenos Aires 1992.

Vera Urbano, Francisco, "La libertad religiosa en el pensamiento católico según los tratados de teología moral y la literatura polémica del siglo XVIII", in Revista de Estudios Histórico - Jurídicos 25 (2003), 445-474. 
Esteban Llamosas - 9789004449749 Downloaded from Brill.com04/26/2023 11:30:32AM via free access 